\title{
AN EMPIRICAL ANALYSIS OF THE FACTORS THAT INFLUENCE INFRASTRUCTURE PROJECT FINANCING BY BANKS IN SELECT ASIAN ECONOMIES
}

Vivek Rao

NO. 554

August 2018
ADB ECONOMICS WORKING PAPER SERIES 


\section{An Empirical Analysis of the Factors that Influence Infrastructure Project Financing by Banks in Select Asian Economies}

Vivek Rao

No.554 | August 2018
Vivek Rao (vrao@adb.org) is a Principal Financial Sector Specialist in the Southeast Asia Department of the Asian Development Bank (ADB).

This paper has been prepared as background material for the Asian Development Outlook (ADO) 2017 Update theme chapter on Sustaining Development through Public-Private Partnership. It was written with the technical and methodological guidance of a team from Bocconi University in Italy led by Professor Stefano Gatti, Director MBA program, SDA Bocconi School of Management; and included Associate Professor Paolo Colla of the Finance Department; Associate Professor Veronica Vecchi; and Professor Francesca Casalini, all from SDA Bocconi School of Management. In addition, the author is thankful to Michael Timbang of ADB for excellent research assistance. The author would also like to acknowledge Joseph Ernest Zveglich Jr., Assistant Chief Economist from the Economic Research and Regional Cooperation Department and Bruno Carrasco, Director from the South Asia Department of ADB, and discussants of the ADO 2017 Update workshop held on 8 June 2017 for very useful discussions and guidance. Finally, the author is grateful to ADB for financial support. 
(C) 2018 Asian Development Bank 6 ADB Avenue, Mandaluyong City, 1550 Metro Manila, Philippines

Tel +632632 4444; Fax +6326362444

www.adb.org

Some rights reserved. Published in 2018.

ISSN 2313-6537 (print), 2313-6545 (electronic)

Publication Stock No. WPS189505-2

DOI: http://dx.doi.org/10.22617/WPS189505-2

The views expressed in this publication are those of the authors and do not necessarily reflect the views and policies of the Asian Development Bank (ADB) or its Board of Governors or the governments they represent.

ADB does not guarantee the accuracy of the data included in this publication and accepts no responsibility for any consequence of their use. The mention of specific companies or products of manufacturers does not imply that they are endorsed or recommended by ADB in preference to others of a similar nature that are not mentioned.

By making any designation of or reference to a particular territory or geographic area, or by using the term "country" in this document, $A D B$ does not intend to make any judgments as to the legal or other status of any territory or area.

This work is available under the Creative Commons Attribution 3.0 IGO license (CC BY 3.0 IGO)

https://creativecommons.org/licenses/by/3.o/igo/. By using the content of this publication, you agree to be bound by the terms of this license. For attribution, translations, adaptations, and permissions, please read the provisions and terms of use at https://www.adb.org/terms-use\#openaccess.

This CC license does not apply to non-ADB copyright materials in this publication. If the material is attributed to another source, please contact the copyright owner or publisher of that source for permission to reproduce it. $\mathrm{ADB}$ cannot be held liable for any claims that arise as a result of your use of the material.

Please contact pubsmarketing@adb.org if you have questions or comments with respect to content, or if you wish to obtain copyright permission for your intended use that does not fall within these terms, or for permission to use the ADB logo.

Notes:

In this publication, “\$” refers to United States dollars.

ADB recognizes "China" as the People's Republic of China; "Hong Kong" as Hong Kong, China; and "Korea" as the Republic of Korea.

Corrigenda to ADB publications may be found at http://www.adb.org/publications/corrigenda. 


\section{CONTENTS}

TABLES

$\begin{array}{ll}\text { I. INTRODUCTION } & 1\end{array}$

II. LITERATURE REVIEW 4

A. Monetary Policy $\quad 5$

B. Bank Factors $\quad 6$

C. How Project Risks Affect Lenders 6

D. Public-Private Partnership Framework $\quad 7$

III. METHODOLOGY AND DATA 8

IV. MODEL ESTIMATION

A. $\quad$ Bank Syndicate-Specific Variables 12

B. Project- or Transaction-Specific Variables 12

C. Macroeconomic Factors 12

V. MODEL ESTIMATION RESULTS

A. Policy Implications 16

B. Comparative Analysis 16

VI. CONCLUSIONS AND DIRECTIONS FOR FUTURE RESEARCH 17

$\begin{array}{ll}\text { APPENDIX } & 19\end{array}$

$\begin{array}{ll}\text { REFERENCES } & 23\end{array}$ 


\section{TABLES}

$1 \quad$ Non-Japan Asia's Infrastructure Competitiveness by Sector $\quad 1$

2 Ease of Doing Business Indicators 2017 Rankings 3

3 Project Finance Deals by Country 9

$4 \quad$ Project Finance Deals by Sector 9

5 Project Finance Deals League Tables 10

6 Project Level Descriptive Statistics 11

$7 \quad$ Drivers of Project-Finance Deals 14

A1 Project Level Descriptive Statistics (Mature Markets) 19

A2 Drivers of Project-Finance Deals (Mature Markets) 20

A3 Sources and Description of Variables 22 


\begin{abstract}
A recent Asian Development Bank publication estimates the large infrastructure financing requirement in Asia for the period 2016-2030, which establishes the strong need to encourage private sector participation to meet investment requirements. This paper analyzes a critical aspect of expanding private finance to infrastructure by examining the role of bank lending to public-private partnership (PPP) projects through the project finance modality. The key empirical results suggest that project financing by banks to infrastructure PPP projects is still in its infancy in several Asian markets, and banks are guided more by macroeconomic factors and by the strength of their balance sheets. The key policy implications to unlock bank finance for infrastructure PPP projects lie in reducing macroeconomic risk factors and having well-capitalized banks. The latter assumes significance, given the higher capital requirements that banks are expected to fulfill, following the adoption of Basel III capital standards.
\end{abstract}

Keywords: project finance, bank lending, infrastructure, public-private partnership

JEL codes: G21, G32, H41, H54 


\section{INTRODUCTION}

The objective of this paper is to explain the factors influencing bank lending for infrastructure financing in Asia, with an emphasis on project financing of public-private partnership (PPP) projects. The paper follows a recent Asian Development Bank (ADB) study which estimates that developing Asia will need to invest $\$ 26$ trillion, or $\$ 1.7$ trillion per year from 2016 to 2030, if the region is to maintain its growth momentum, eradicate poverty, and respond to climate change (ADB 2017). While the region currently invests an estimated $\$ 881$ billion in infrastructure, the infrastructure investment gap, i.e., the difference between current investment levels and investment needs expressed as a share of projected gross domestic product (GDP) for these economies, works out to $1.7 \%$ (baseline) or $2.4 \%$ (climate-adjusted) over the 2016-2020 period, focusing on 25 economies that include $96 \%$ of Asia's population. The key question that emerges is how this investment will be financed.

Developing Asia has seen dramatic improvements in transport, power generation capacity, telecommunication, and water infrastructure, while improved infrastructure has driven growth, reduced poverty, and improved lives, the state of infrastructure across non-Japan Asia (NJA) varies widely. While Singapore and Hong Kong, China are at the vanguard of global infrastructure rankings, emerging economies such as Malaysia, the People's Republic of China, and Thailand also rank in the

Table 1: Non-Japan Asia's Infrastructure Competitiveness by Sector

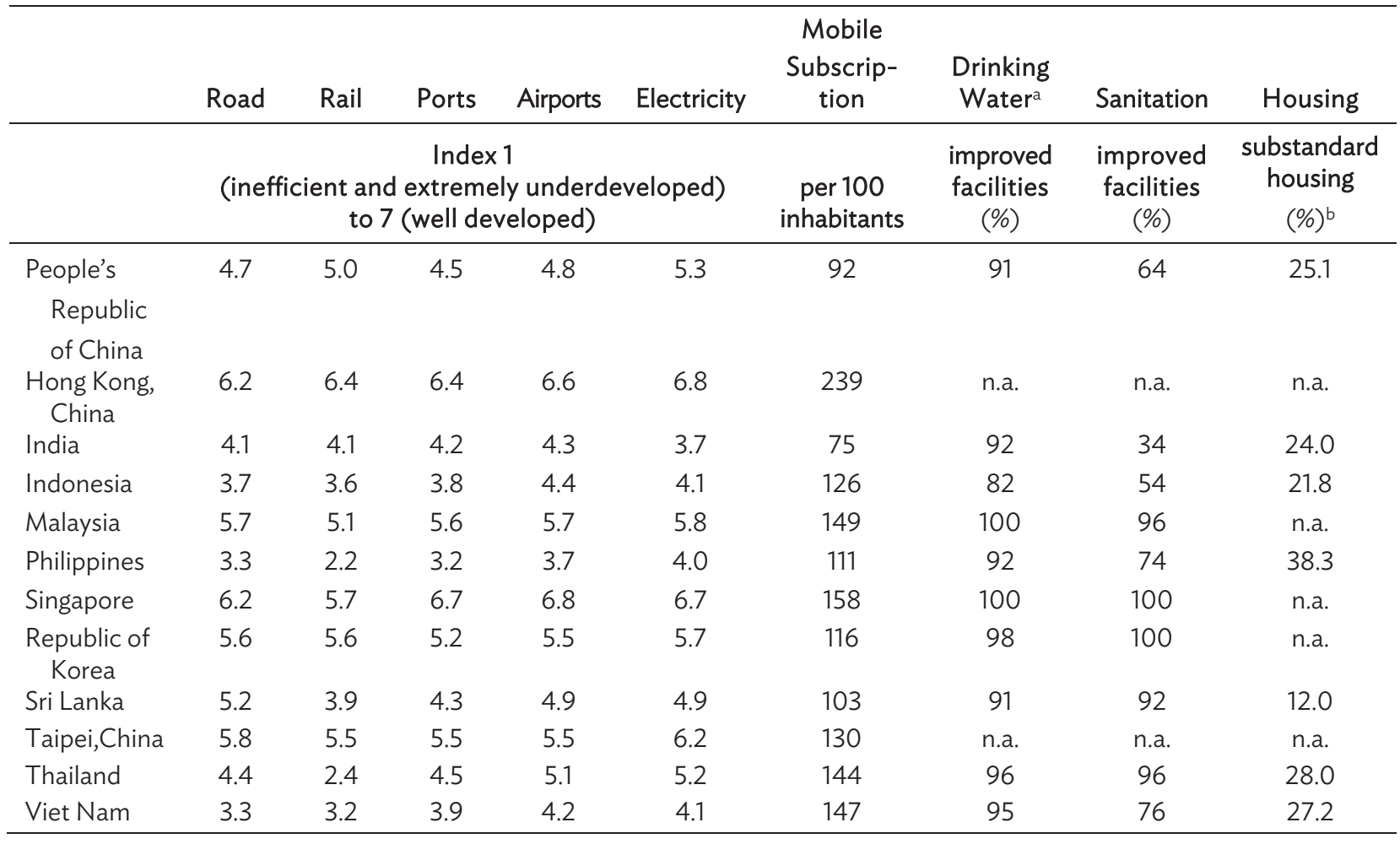

n.a. $=$ not available.

a Improved facilities, according to the UN Joint Monitoring Programme database, refers to facilities which are more likely to provide safe drinking water and ensure privacy and hygienic use.

b Percent of urban population living in substandard housing.

Source: Hansakul, Syetarn, and Hannah Levinger. 2016. "Asia Infrastructure Financing: Getting It Right would Lift Medium-Term Growth." Deutsche Bank Research, Current Issues: Emerging Markets. 
top half. On the other hand, infrastructure availability in India, Indonesia, and the Philippines remains weak. Accordingly, as of 2015, over 400 million Asians lack power, around 300 million have no access to safe drinking water, and 1.5 billion lack basic sanitation. Table 1 provides an overview of the state of infrastructure in NJA. ${ }^{1}$

The public sector can reduce the investment gap by increasing infrastructure investment. This can be done by mobilizing public finances through tax reforms, infrastructure tariffs, and land value capture. ${ }^{2}$ Overall, the International Monetary Fund estimates that 22 of the 25 largest developing Asian economies can sustainably increase revenues via policy reform. ${ }^{3}$ However, limitations still exist in expanding public resources for infrastructure financing relative to requirements.

Considering the infrastructure investment gap and the financing requirements, the role of the private sector has assumed increasing importance. The role of the private sector has largely emerged through the PPP modality, requiring debt and equity investments in project-specific special purpose vehicles (SPVs). As indicated, debt requirements during project construction are provided by banks for using project finance techniques.

To promote project financing through the PPP modality, regulatory, legal, institutional, and finance sector reforms are required (OECD 2014, Vecchi et al. 2017). While PPPs are high on the agenda of several governments and private sector companies, their popularity varies across sector and geography. Understanding the incentives for various stakeholders in a PPP transaction is key to this debate. According to the World Bank's Public-Private Partnership Reference Guide, PPPs can help overcome some of the key challenges of infrastructure delivery, including insufficient funds, poor planning and project selection, inefficient or ineffective delivery, and inadequate maintenance. ${ }^{4}$ In the context of the need to expand infrastructure availability, Table 2 provides a picture of factors in Asian economies resulting in a relatively weak investment climate.

An additional argument in support of the development role of PPP is that private sector investment acts as a skimming tool that avoids white elephants as investment decisions focus on life cycle aspects, including timelines, quality standards, budgets, and financial sustainability (Vecchi, Airoldi, and Caselli 2015). Thus, with limitations to sustainably increasing public investment, PPPs can be used as a matching fund or complementary investment opportunity with the advantage of avoiding investments that can become white elephants.

1 NJA refers to Hong Kong, China; India; Indonesia; Malaysia; the People's Republic of China; the Philippines; the Republic of Korea; Singapore; Sri Lanka; Taipei,China; Thailand; and Viet Nam.

2 Monetizing rising land values as infrastructure is built.

3 In the Philippines, for example, the International Monetary Fund and the World Bank have estimated that tax reform (including rationalization of tax incentives and reducing value-added tax exemptions) along with improving tax administration can yield an estimated $2 \%-3 \%$ of GDP in additional revenue. This is in line with the government's own estimates. In Sri Lanka, simplifying the tax system and broadening the tax base can generate 2.9\% of GDP in additional revenue.

4 World Bank, ADB, and Inter-American Development Bank. 2014. Public-Private Partnership Reference Guide 2014. Washington, DC. The work is a product of the staff of the World Bank, ADB, and the Inter-American Development Bank with external contributions. 
Table 2: Ease of Doing Business Indicators 2017 Rankings

\begin{tabular}{lccc}
\hline Economies & Ease of Doing Business & Starting a Business & Getting Electricity \\
\hline People's Republic of China & 78 & 127 & 97 \\
Hong Kong, China & 4 & 3 & 3 \\
India & 130 & 155 & 26 \\
Indonesia & 91 & 151 & 49 \\
Malaysia & 23 & 112 & 8 \\
Philippines & 99 & 171 & 22 \\
Singapore & 2 & 6 & 10 \\
Republic of Korea & 5 & 11 & 1 \\
Sri Lanka & 110 & 74 & 86 \\
Taipei,China & 11 & 19 & 2 \\
Thailand & 46 & 78 & 37 \\
Viet Nam & 82 & 121 & 96 \\
\hline
\end{tabular}

Source: World Bank. 2017. Doing Business 2017: Equal Opportunity for All. Washington, DC.

In addition, assuming superior technical and servicing capacity by private parties, PPPs can improve the quantity and quality of service delivery, thus creating better value for money compared with traditional public procurement (Vecchi et al. 2017). In the case of bundled contracts, the project sponsors have an incentive to incur high capital costs during construction to reduce operation and maintenance costs during operation, leading to improved productive efficiency. These efficiency gains are needed to compensate for the higher costs of private finance due to improvements in design, construction, and operation of the asset. Further, depending on the sector, asset, and the location, PPPs also represent an attractive opportunity for institutional investors. According to the World Economic Forum (WEF), the demands of global institutional investors that manage trillions of dollars who seek a diversified portfolio with attractive returns have incentivized the launch of infrastructure funds, contributing to the financialization of infrastructure (WEF 2013). ${ }^{5}$ As the WEF argues, "infrastructure project risk-return profiles present an attractive alternative investment especially with real fixed income returns being near zero in the wake of the global financial crisis" (WEF 2013).

This paper fills a void in the literature on the use of syndicated project finance loans for private and PPP projects in the selected Asian economies. Further, this paper is possibly the only academic contribution that explicitly analyzes how the economic fundamentals of banking (capital levels, profitability, asset riskiness, and cost efficiency) impact on project finance lending and, via this lending, on the amount of debt provided to infrastructure financing in Asia.

To begin with, Esty (2004) points out that academic papers on project finance are very limited and are strongly focused on adapting traditional corporate finance literature to structured finance products, but fail to analyze the peculiar features of the deal. Similarly, Corielli, Gatti, and Steffanoni (2010) point out that project finance is a topic that deserves further attention compared with what the academic literature has analyzed so far. This paper is centered on the study of bank syndicates in Asia,

5 According to Inderst (2010), time series data on performance of unlisted infrastructure funds in Australia over a 10-year period ending the second quarter of 2006 show the volatility of unlisted infrastructure (5.8\%) is lower than listed asset classes, but higher than bonds (4.3\%) and property (1.5\%). Not surprisingly, listed infrastructure shows both higher returns and risk than unlisted infrastructure assets, as financing agreements in unlisted deals allow investors to better capture key features such as lower sensitivity to economic and market swings. The Sharpe ratio for property assets is highest (3.67), while unlisted infrastructure (1.47) comes second, with stocks (0.67) and bonds (0.39) ranked lowest. This shows that, per unit of volatility, unlisted infrastructure assets provide better returns than listed stocks and bonds. 
and tries to shed light on the behavior of banks in this branch of the structured finance field. Second, our paper contributes to the literature on PPPs that is only rarely seen in association with project finance. The Hammami, Ruhashyankiko, and Yehoue (2006) paper is an excellent study on the determinants of PPPs, but lacks focus on the lenders' side and on factors impacting investment in projects. Finally, this paper is a link between banks' literature on the economic determinants of lending and project financing.

The foundations of the paper and the basis for the empirical analysis are derived from the literature review that focuses on the entire range of issues that potentially impact bank lending on project finance type investments in infrastructure PPP projects. Following the literature review, the paper discusses the data requirements and sources and provides broad diagnostics on the data. Subsequently, the paper analyzes the estimation of the empirical model and provides policy implications. The paper suggests that project financing of infrastructure PPP projects is still in its infancy in the Asian economies considered, and banks are guided more by macroeconomic risk factors and the strength of their balance sheets. However, the comparative analysis of mature PPP markets stresses the transaction nature of bank lending. The paper ends with guidance for further research.

\section{LITERATURE REVIEW}

Financing of PPP infrastructure projects requires equity, debt, and instruments like project bonds. While banks play a key role in infrastructure financing, they are challenged by the inherent assetliability mismatches as banks typically have short-term liabilities and infrastructure financing involves long-term assets (Ma 2016). Further, as financing requirements are large, loans often come under a syndicate due to the limits on single-party exposure as required by regulatory guidelines.

Banks typically finance the initial stage of an infrastructure project finance transaction. Bank loans have several advantages over bonds or other structured instruments as (i) banks provide an important monitoring role; (ii) infrastructure projects need gradual disbursement of funds, and bank lending has the required flexibility; and (iii) infrastructure projects are relatively more likely to require debt restructurings in unforeseen events, and banks can quickly negotiate restructurings with each other (Esty and Megginson 2003). Banks take on higher project risk during construction, which subside in the operation phase at which time bond financing and other structured instruments are more attractive for long-term investors in this asset class (Gatti 2012).

In addition, bank lending to PPP infrastructure projects is influenced by the monetary policy stance of the central bank, the PPP policy framework in the country. In this context, the literature has also focused on (i) the role of nonfinancial contracts in mitigating project risk; (ii) the state of banks with respect to their nonperforming loans and profitability; (iii) the availability of risk mitigation instruments for projects; (iv) the reputation of the sponsor and the lead arrangers in syndicated project finance transactions; and ( $v$ ) the depth and liquidity in complementary financing markets such as the capital markets. This section provides a perspective on the various factors that potentially impact bank lending to infrastructure projects. 


\section{A. Monetary Policy}

In an influential paper, Bernanke and Gertler (1995) point out that the credit channel for monetary transmission works through the supply side and amplifies the more traditional money channel. When a central bank tightens monetary policy by squeezing reserves, it generates a corresponding reduction in the supply of bank loans. However, this will result in a real contraction, only if banks cannot change the composition of their liabilities by issuing certificates of deposits or bonds, and firms cannot shift to bonds and commercial papers. The money channel emphasizes the impact of a monetary tightening on the balance sheets of firms and impact on asset prices, and thus market value of wealth.

In a related article, Kashyap and Stein (1994) present evidence that as, with firms, banks also cannot seamlessly generate loanable funds when tighter monetary policy restricts banks' ability to generate loans from deposits. The alternative avenues available to banks to raise funds include largedenomination certificates of deposits, medium-term notes, and other securities not subject to regulatory restrictions. However, they point out that these securities are not subject to deposit insurance and similar types of arrangements, and can only be issued at higher costs and to investors with different risk appetites. Accordingly, due to capital market imperfections, shocks to the deposit base cannot be offset with other sources of financing and, therefore, translate into real effects on lending behavior.

More recently, Disyatat (2010) questions the link between bank deposits and the money multiplier (credit channel), suggesting that the ability or willingness of banks to provide credit is influenced more by bank capital and the risk to bank balance sheets. The bank lending channel may also be reinforced by the impact of monetary policy on perceptions of risk and/or willingness to bear risk. The case for such links has been put forward by Bernanke and Gertler (1995) and Borio and Zhu (2008). The latter refer to this mechanism as the risk-taking channel. ${ }^{6}$ One avenue through which such effects may work is via the impact of interest rates on financial buffers or the perceived vulnerability of agents to future economic shocks. For example, a policy tightening may raise firms' perceived riskiness by increasing tensions on cash flows and weakening balance sheets. Anticipation of slower economic activity may raise the risk of bankruptcy. As emphasized, the pro-cyclical behavior of estimates of default probabilities and loss given default can also be a manifestation of the influence of risk perceptions that is driven in part by monetary policy. The level of interest rates may also influence riskier behavior, as when interest rates are low. The search for yield leads to expansion of investments into riskier assets as downside risks are downplayed.

Further, the role of monetary policy, in response to inflation also impacts project financials and bank lending. The impact of inflation, as analyzed by Visconti (2012), occurs through the relative impact on the weighted average cost of capital (WACC) and the net present value (NPV). Given this, increases in the inflation rate (i) un-ambiguously increases the denominator in the NPV equation, and thus reduces the NPV itself; and (ii) increases the cost of debt (as bank debt is floating and indexed to inflation) and, therefore, increases WACC. Thus, very real scenarios arise that with higher inflation, the WACC may exceed NPV and could result in equity as well as cash burnout.

6 The original discussion on bank lending channel by Bernanke and Blinder (1988) also raises the possibility of a link between perceived riskiness of loans and banks' supply of loans, but not in the context of changes in monetary policy. 


\section{B. Bank Factors}

Analyzing a broad range of potential factors on determinants of bank credit, Pham (2015) uses data on 146 countries over 1990-2013. The results suggest that the key factors restricting credit supply include nonperforming assets, capital requirements, and bank concentration. However, the results do not find any evidence on the impact of return on equity/return on assets (ROE/ROA) on bank credit supply. In a related paper, Mirzaei and Mirzaei (2011) determine that factors such as cost to income ratio and capital ratio are the key determinants of profitability, suggesting that higher levels of capitalization reduce funding costs for banks. A key finding of the study is the significant negative relationship between profitability and the net loans to deposits and short-term funds ratio. This indicates that lending by banks based on short-term deposits negatively impacts bank profitability.

Kirti (2017) suggests that the banks' liability structure drives the interest rate exposure of assets, implying that banks with more floating rate liabilities make more floating rate loans. The results establish an important link between the intermediaries' funding structure and the types of contracts used by nonfinancial forms. The author shows that banks achieve this by passing on interest rate risk to firms. ${ }^{7}$ Two other recent papers advance related arguments. Ivashina, Scharfstein, and Stein (2012) argue that hedging frictions make it advantageous for banks to lend in the same currency as their deposit financing. Hanson et al. (2014) argue that the types of assets intermediaries hold depend on the stability of their funding. More broadly, Kirti (2017) is also connected with the view that there are synergies between deposits and commitments (Kashyap, Rajan, and Stein 2002), and that intermediaries must themselves be incentivized to monitor (Diamond 1984, and Holmström, and Tirole 1998).

\section{How Project Risks Affect Lenders}

The allocation and management of risks in PPP project finance transactions and general purpose corporate lending differ. As project finance lenders are dependent on project cash flows and do not have recourse to the sponsor balance sheets, short-term exposure can put pressure on the early stage of a project, and thus increases the risk of default (Sorge and Gadanecz 2004). This contrasts with corporate finance lending where shorter maturities are considered less risky, suggesting that the standard upward sloping relationship between credit risk and loan maturity may not apply in project finance. In addition, projects usually go through construction and operations phases, each of them characterized by specific risks and mitigates. Thus, it is likely that incrementally extending loan maturities after the scheduled time for the project to be operational might drive up the ex-ante risk premium but at a decreasing rate, based on the risk allocation mechanism and availability of mitigates such as guarantees.

Governments may also employ credit-enhancement tools to promote PPP bankability, as in a minimum payment guarantee to reduce demand risk where the contracting authority guarantees a minimum revenue. The minimum revenue guarantee is generally enough to cover debt servicing at some level of the debt service coverage ratio or to reach a minimum return. A World Bank study finds that the debt service coverage ratio requested by banks is lower in the presence of a minimum guarantee. In addition, a guarantee that services the principal and interest in the case of default may

7 Garcia-Appendini, Gatti, and Nocera (2017) analyze how banks' funding policies using covered bonds can have an impact on the inclination of banks to lend and to change the overall asset risk of the intermediary. 
also be used. This approach is widely used to mitigate default risk, and reduces the need for lenders to make fresh exposures to stressed projects. ${ }^{8}$

Corielli, Gatti, and Steffanoni (2010) analyze nonfinancial contracts with third parties, which reduce the credit risk to the lender and lower financing costs. These include (i) purchasing agreements that guarantee raw material to the SPV at predefined quantities, quality, and prices (raw material cost and availability risk shifting); (ii) off-take agreements that enable the SPV to sell part or all of its output to a party that commits to buy at predetermined prices and for a given period of time (market risk shifting); and (iii) operation and maintenance agreements to provide the SPV with maintenance at a level compliant with predefined service-level agreements. They find evidence that, while nonfinancial contracts lower the risk profile of projects, lenders may be unwilling to reduce rates if the sponsor is a counterparty in the relevant contract.

In addition to nonfinancial contracts, project finance transactions also rely on financial contracts to make cash flows verifiable by (i) contractual arrangements made possible by structuring the project within a single, discrete entity, legally separate from the sponsor; and (ii) private enforcement of these contracts through a network of project accounts that ensures lender control of project cash flows. Accordingly, comparing bank loans for project finance with regular corporate loans for large investments, Subramanian and Tung (2016) show that project finance is more likely in countries with weaker laws against insider stealing and weaker creditor rights in bankruptcy.

\section{Public-Private Partnership Framework}

The project finance structure underlying PPP projects is a response to the agency problem that arises from the differing and conflicting interests of various parties involved in an infrastructure project. In the case of PPP project finance structure, a complex series of contracts and financing arrangements distributes the different risks presented by a project among the various parties involved in the project, including sponsors and investors, lenders, contractors, suppliers, and the government. In many cases, the project company retains ownership of the project assets.

In this context, Brealey, Cooper, and Habib (1996) argue that the widespread use of bank finance and the limited use of bond finance in PPP-type project finance is a response to the agency problem and the consequent need for close monitoring of an infrastructure PPP project in the initial stages. The role of bank and bond investors follows the ownership structures of these two types of financing. The concentrated ownership of bank debt encourages the lending banks to devote considerable resources to evaluating and monitoring a project on a continuing basis. It also facilitates the renegotiation of the debt should the project company experiences servicing challenges. By contrast, the diffused nature of bond ownership makes it difficult to take concerted action if covenants are breached or if they require modification.

PPP project finance contract structure also has implications on the resulting incentives and project costs. Blanc-Brude, Goldsmith, and Välilä (2006) draw from insights provided by Hart (2003) with respect to bundling and unbundling of project contracts to provide evidence supporting increased project costs in PPP projects. The empirical results point to a $24 \%$ increase in capital costs in PPP projects compared with projects procured through the traditional route. On balance, while unbundling will unambiguously lead to reduction in productive efficiency, the reduction in allocative efficiency in

8 In the event of a default, the existing lenders may have to take a fresh exposure to the stressed project to enable the project to make good accumulating interest payments. 
the case of bundling may be balanced with the improvements in productive efficiency. The ability to contract out investments also plays a role in choosing between bundled and unbundled contracts. In case the investment associated with productive efficiency can be contracted out but the investment associated with allocative efficiency cannot, the unbundling is superior. The converse is true if the investment related to allocative efficiency can be contracted out, but not the investment related to allocative efficiency.

\section{METHODOLOGY AND DATA}

The paper employs data extracted from Thomson One Banker regarding project-level information on bank-financed PPP deals between 2011 and 2016 in India, Indonesia, Malaysia, the Philippines, the Republic of Korea, Thailand, and Viet Nam. For a project to be included in the dataset, complete information on project name, type and sector, financial close date, cost, gearing ratio, and borrower name is required. After excluding five all-equity financed projects, the dataset yields 483 unique projects. The total project cost amounts to $\$ 163.3$ billion, with total project debt (obtained multiplying project cost by its gearing ratio) of $\$ 133.3$ billion. This corresponds to an average gearing ratio of about $82 \%$, which confirms the highly leveraged nature of project finance transactions in the countries under examination. Then, data from Thomson One Banker on loan (tranches) characteristics including loan amount, maturity, currency, type of security, and banks (mandated arrangers, by ultimate parent) are retrieved. Projects are typically funded by more than one tranche, and only information for term loans is retained. The reason is that these tranches of the syndicated financing are earmarked for construction and thus capture the essence of project to support long-term infrastructure investments. Based on these information, consistent data on 413 projects funded by 108 unique banks via 626 term loans is extracted.

Next, data on bank balance sheet items for mandated arrangers are obtained from Orbis Bank Focus. These include tier 1 capital ratio as a proxy for capital adequacy, return on average assets (ROAA) as a proxy for earnings quality, loans (over total assets) and impaired loans (over gross loans) as proxies for asset quality, liquid over total assets as a proxy for liquidity, and cost to income ratio as a proxy for efficiency. Balance sheet items are measured during the same year of a project's financial close. The quality of balance sheet information varies across items. While ROAA, and cost to income are reported by most banks (about 82\%), tier 1 capital ratio is available for a smaller set of banks (60\% of observations). Since no information about each arranger's participation in a loan tranche is available, it is assumed that banks take equal shares in providing funds. ${ }^{9}$ Thus, for each project, banks' balance sheet items are syndicate-level averages of bank-level items. ${ }^{10}$ At this stage, loans (and thus projects), for which balance sheet items are unavailable for all banks in the syndicate, are dropped. The final sample consists of 244 projects funded by 88 unique banks via 367 loans. These projects represent about $45 \%$ of the total sample in terms of total project cost of $\$ 74.4$ billion with a total debt of $\$ 57.2$ billion.

Table 3 provides a breakdown of projects by country, with India accounting for the largest number of projects in the data set. However, in terms of economic value, country representation differs from what is obtained when considering the number of projects. While India still accounts for almost $50 \%$ of total project companies and project debt, the size of projects financed in Viet Nam and Indonesia is significantly larger on the average.

9 Equal sharing is assumed based on the literature Esty (2001). In particular, the author assumes equal commitment on loan underwriting when estimating the fee distribution among the lead and co-lead arrangers. In addition, Gatti et al. (2013) also use the same assumption where no data on the composition of the syndicate is provided.

10 In virtually all instances, the composition of the syndicate is the same across tranches for a given project. In those cases (10 projects), where banks differ across tranches, syndicate size is defined as the number of unique banks providing financing across all tranches. 
Table 3: Project Finance Deals by Country

\begin{tabular}{lcccccc}
\hline Country & $\begin{array}{c}\text { Project } \\
\text { Cost } \\
(\$ \text { billion })\end{array}$ & $\begin{array}{c}\text { Total Project } \\
\text { Cost } \\
(\%)\end{array}$ & $\begin{array}{c}\text { Debt } \\
(\$ \text { billion })\end{array}$ & $\begin{array}{c}\text { Total Debt } \\
(\%)\end{array}$ & $\begin{array}{c}\text { Number of } \\
\text { Projects }\end{array}$ & $\begin{array}{c}\text { Total } \\
\text { Projects } \\
(\%)\end{array}$ \\
\hline India & 35.02 & 47.1 & 27.16 & 47.5 & 118 & 48.4 \\
Indonesia & 7.34 & 9.9 & 5.88 & 10.3 & 13 & 5.3 \\
Malaysia & 3.81 & 5.1 & 3.06 & 5.4 & 10 & 4.1 \\
Philippines & 3.64 & 4.9 & 2.79 & 4.9 & 6 & 2.5 \\
Republic of Korea & 5.59 & 7.5 & 4.92 & 8.6 & 20 & 8.2 \\
Thailand & 6.72 & 9.0 & 6.00 & 10.5 & 72 & 29.5 \\
Viet Nam & 12.23 & 16.4 & 7.40 & 12.9 & 5 & 2.0 \\
\hline Total & 74.35 & & 57.21 & & 244 & \\
\hline
\end{tabular}

Source: Author's estimates based on Thomson One Banker.

Based on the description given in Thomson One Banker, projects are grouped into five sectors. The sectorwise classification in Table 4 shows that the energy sector accounts for the bulk of the projects; followed by transport; and mining, oil, and gas. While the manufacturing sector projects are relatively few, their average size in terms of cost and debt is significantly larger than projects in other sectors. Consequently, the manufacturing sector accounts for around $25 \%$ of total project cost.

Table 4: Project Finance Deals by Sector

\begin{tabular}{lccccc}
\hline & $\begin{array}{c}\text { Project } \\
\text { Cost } \\
\text { (\$ billion) }\end{array}$ & $\begin{array}{c}\text { Total Project } \\
\text { Cost } \\
(\%)\end{array}$ & $\begin{array}{c}\text { Debt } \\
\text { (\$ billion) }\end{array}$ & $\begin{array}{c}\text { Number of } \\
\text { Projects }\end{array}$ & $\begin{array}{c}\text { Total Projects } \\
(\%)\end{array}$ \\
\hline Energy & 31.70 & 42.60 & 26.24 & 158 & 64.80 \\
Manufacturing & 18.61 & 25.00 & 11.90 & 11 & 4.50 \\
Mining, oil, and gas & 9.80 & 13.20 & 7.43 & 24 & 9.80 \\
Transport & 13.67 & 18.40 & 11.00 & 45 & 18.40 \\
Others & 0.60 & 0.80 & 0.58 & 6 & 2.50 \\
\hline Total & 74.38 & & 57.21 & 244 & \\
\hline
\end{tabular}

Source: Author's estimates based on Thomson One Banker.

Regarding the syndicate composition and banks' contribution to project finance deals, while most projects are financed by a single bank, around $25 \%$ of projects involve two mandated arrangers. Overall, there are 90 unique syndicates, out of which 16 are single banks. Table 5 reports league tables for the top 10 banks in terms of projects funded and debt composition. The leading bank for project lending is Kasikornbank in Thailand which financed 54 projects, of which it financed 21 as a single financer. Next, the most active bank is the State Bank of India which participated in 43 deals of which 34 are financed as a single financier. In terms of economic value, the State Bank of India alone accounts for about $24 \%$ of total debt in the sample. The involvement of banks headquartered outside the target countries is more limited, with only three banks; namely, the Mitsubishi UFJ Financial Group, the Standard Chartered Bank, and the Sumitomo Mitsui Financial Group, entering the league tables. 
Table 5: Project Finance Deals League Tables

\begin{tabular}{|c|c|c|c|}
\hline Name of Bank & $\begin{array}{l}\text { Number of } \\
\text { Projects }\end{array}$ & Name of Bank & $\begin{array}{c}\text { Debt Amount } \\
\text { Financed (\$ billion) }\end{array}$ \\
\hline Kasikornbank (Thailand) & 54 & State Bank of India & 13.78 \\
\hline State Bank of India & 43 & Axis Bank (India) & 5.34 \\
\hline Axis Bank (India) & 26 & $\begin{array}{l}\text { Korea Development Bank } \\
\text { (Republic of Korea) }\end{array}$ & 2.66 \\
\hline $\begin{array}{l}\text { Sumitomo Mitsui Financial Group } \\
\text { (Japan) }\end{array}$ & 21 & IDBI Bank (India) & 1.75 \\
\hline $\begin{array}{l}\text { Korea Development Bank } \\
\text { (Republic of Korea) }\end{array}$ & 20 & Kasikornbank (Thailand) & 1.66 \\
\hline Mitsubishi UFJ Financial Group & 19 & $\begin{array}{l}\text { Sumitomo Mitsui Financial Group } \\
\text { (Japan) }\end{array}$ & 1.54 \\
\hline Siam Commercial Bank (Thailand) & 17 & Yes Bank (India) & 1.48 \\
\hline Yes Bank (India) & 17 & $\begin{array}{l}\text { Standard Chartered Bank } \\
\text { (United Kingdom) }\end{array}$ & 1.37 \\
\hline $\begin{array}{l}\text { Standard Chartered Bank } \\
\text { (United Kingdom) }\end{array}$ & 16 & Mitsubishi UFJ Financial Group & 1.31 \\
\hline Krung Thai Bank (Thailand) & 15 & China Development Bank & \\
\hline
\end{tabular}

Source: Author's estimates based on Thomson One Banker.

Moreover, the descriptive statistics of project-level variables in Table 6 indicates that the average project cost is $\$ 304$ million, a gearing ratio of $86.94 \%$, and an original maturity of about 13 years. Its financing witnesses the involvement of two banks that commit funding by means of 1.5 term loans. As far as the syndicate composition is concerned, bilateral and multilateral development banks participate, on the average, in 1 out of 10 projects. ${ }^{11}$ Within each syndicate, about $85 \%$ of the mandated arrangers are local banks, i.e., banks headquartered in the country where the project is financed. Apparently, the data indicates a strong arranger certification requirement of local banks for infrastructure, particularly toward international and/or nonlocal lenders that may find it hard to invest in these projects without leveraging on market knowledge provided by the local mandated lead arranger. In addition, $75 \%$ of projects are financed in local currency, while debt financing for the other $25 \%$ involves foreign currency for at least one tranche. The typical arranger in the sample shows a solid tier 1 level of about 12\%, but a relatively low profitability as measured by an ROAA of $1.22 \%$. Loans and liquidity account for almost $70 \%$ of total assets and the loan portfolio exhibits a relatively low degree of riskiness (2.8\%). The efficiency in terms of cost-income ratio is found at about $54 \%$.

1 Multilateral development banks in the sample are ADB, and the International Finance Corporation; bilateral development banks including the China Development Bank, the Development Bank of Japan, the Netherlands Development Finance Company (FMO), KfW (through German development cooperation), IPEX-Bank GmbH, and the Korea Development Bank. 
Table 6: Project Level Descriptive Statistics

\begin{tabular}{|c|c|c|c|c|}
\hline Variable & Mean & p50 & $\mathrm{p} 5$ & p95 \\
\hline Gearing & 86.94 & 97.26 & 63.98 & 100.00 \\
\hline Cost & 304.87 & 109.30 & 14.80 & 1300.40 \\
\hline Maturity (equally weighted) & 12.94 & 13.46 & 6.18 & 20.01 \\
\hline Tranches & 1.50 & 1.00 & 1.00 & 3.00 \\
\hline Local currency & 0.75 & 1.00 & 0.00 & 1.00 \\
\hline Foreign currency & 0.25 & 0.00 & 0.00 & 1.00 \\
\hline Syndicate size & 1.99 & 1.00 & 1.00 & 5.00 \\
\hline Multilateral development bank & 0.10 & 0.00 & 0.00 & 1.00 \\
\hline Local bank & 0.83 & 1.00 & 0.00 & 1.00 \\
\hline Tier 1 & 11.92 & 12.31 & 8.50 & 15.65 \\
\hline Return on average assets & 1.22 & 1.25 & 0.31 & 2.13 \\
\hline Loans & 58.45 & 60.78 & 43.51 & 67.83 \\
\hline Nonperforming loan & 2.84 & 2.62 & 0.76 & 5.65 \\
\hline Liquid assets & 11.27 & 9.91 & 4.99 & 23.19 \\
\hline Cost/Income & 53.69 & 53.42 & 38.30 & 72.09 \\
\hline
\end{tabular}

Source: Authors estimates based on Thomson One Banker.

As indicated in the literature review, factors influencing bank lending also include macroeconomic and country risk factors. Accordingly, the dataset is complemented with country-level variables that proxy for economic and institutional conditions. Specifically, GDP per capita is used as a proxy for market conditions, inflation as a proxy for macroeconomic stability, and government debt as a proxy for government indebtedness, which are also indicative of country risk. Indicators of political stability and regulatory quality are also considered since both the political environment and the institutional quality may affect PPP investment, obtained from World Development Indicators of the World Bank. Finally, country-level investment in PPP (as a percentage of GDP) is included as an indicator of project-finance experience that may favor the financing of these projects, obtained from the World Bank Private Participation in Infrastructure database. Table A3 details the description of the variables used in this study, and the respective data sources.

\section{MODEL ESTIMATION}

The hypothesis on what determines bank lending to PPP projects in Asia is tested on the factors influencing bank exposure to projects with varying gearing ratios that measure leveraging at the project level. Specifically, the empirical model is expressed as:

$$
\text { Gearing }=\alpha+\beta_{1} \text { Bank Variables }+\beta_{2} \text { Project Variables }+\beta_{3} \text { Country Variables }+\varepsilon
$$

The choice of gearing ratio as the dependent variable is based on the seminal paper by Corielli, Gatti, and Steffanoni (2010) where the debt-equity ratio is regressed on a set of dependent variables, including ratings and currency risk to determine the factors affecting project leverage on project finance transactions. The SPV managers must decide how much equity is required from sponsors and external debt to achieve financial close, which also has a bearing on the cost of debt the SPV can service. In providing debt, external lenders are guided by exogenous heterogeneous risk factors and the amount of equity cushion required for providing debt.

Consequently, the choice of using a variable for project leverage as the dependent variable has several advantages. (i) It captures the role of equity in achieving financial close of projects and 
determines the amount of debt banks are willing to lend per unit of equity. (ii) The leverage aspect is relevant in the context of project finance transactions. (iii) It captures the heterogeneous risk factors across macroeconomic and project-related considerations. Accordingly, three broad set of factors constitute the independent variables, namely (i) syndicate balance sheet items, (ii) project variables, and (iii) country or macroeconomic factors.

Based on the literature review, the factors that can potentially impact bank lending and the reasons for the same are provided below.

\section{A. Bank Syndicate-Specific Variables}

The variables from bank balance sheets that are expected to impact bank lending decisions include nonperforming assets, bank capitalization, and ROE/ROA. It is expected that nonperforming assets will negatively impact bank lending, while higher capitalization and higher ROE/ROA are expected to positively impact bank lending. However, the lending rate is not included because data is not available in most cases. While data availability is a key constraint, lending decisions also more often reflect bank balance sheet variables and the length of relationship banks have with the project sponsor, rather than the lending rate. In addition, the number of banks in a syndicate may have a positive impact in expanding bank lending, especially where the legal risk is high. Finally, a dummy variable in the presence of multilateral development banks in the syndicate can indicate if such institutions provide additional comfort to deposit-taking banks.

\section{B. Project- or Transaction-Specific Variables}

The project- or transaction-specific variables that influence bank lending include project size. Further, as it is not possible to obtain project-specific risk data, loan tenor is used to proxy for project risk. While projects need longer tenors, longer tenor exposes banks to higher liquidity risk. ${ }^{2}$

\section{Macroeconomic Factors}

While the above variables are microeconomic in nature since they are bank- and project-specific, macro variables also impact bank lending decisions. First, following Hammami, Ruhashyankiko, and Yehoue (2006), GDP is included as an instrument to measure market size and to proxy for the potential for risk diversification. Second, the inflation rate plays a role in potentially increasing the WACC relative to the NPV, translating into credit risk to lenders. Additional factors reflecting macroeconomic risk include government debt to GDP ratio that measures the possibility of sovereign default, as well as volatility estimates of GDP growth, inflation, and exchange rate..$^{13}$ In an additional effort to focus on the state of the enabling environment and investment climate, the level of investment in PPP projects as percentage of GDP and indexes for political stability and regulatory quality are included.

12 As longer tenor bank loans will be more difficult to come by as Basel III capital standards kick in, the role of debt capital markets will gain further prominence in the years to come.

13 Following Acemoglu et al. (2003), volatility of GDP growth is measured as the standard deviation of lagged values of GDP growth rates. Volatility of inflation rate follows the same logic. Volatility of exchange rates is computed as the standard deviation of the first difference of logarithms of the local currency versus United States dollar exchange rate (Clark et al. 2004). The volatility estimates use data of the 20 lagged quarters together with the current quarter. 


\section{MODEL ESTIMATION RESULTS}

Table 7 reports ordinary least squares regression results based on the estimated empirical model in Section IV. Since some of the project-level variables (cost, maturity, tranche number, and foreign currency) are simultaneously determined with the gearing ratio, specifications with and without these variables are considered. All regressions include sector fixed effects. Standard errors are clustered at the syndicate level to account for correlation among projects financed by the same syndicate of banks. ${ }^{14}$

Column (1) reports regression results using syndicate characteristics only, while column (2) augments the explanatory variables by including project characteristics. The results document a positive and significant association with tier 1 ratio, liquid-to-total assets ratio, and cost-to-income ratio, while other variables are broadly insignificant. Thus, banks with a more solid capital base or more liquid asset base, as well as less-efficient banks, are more willing to lend to project finance-based PPP transactions. One possible explanation of the fact that banks with a higher cost-to-income ratio lend more is that they may be looking for increasing their performance by lending higher loan amounts, considering that administrative costs tend to be fixed regardless of the size of the deal. Indeed, infrastructures provide the opportunity to increase the average size of any single loan transaction. The coefficient estimates in columns (1)-(2) imply that a one-standard deviation increase in (i) tier 1 increases the gearing ratio by $2.9 \%-3.5 \%$; (ii) liquid-to-total assets ratio increases the gearing ratio by $3.8 \%-4.4 \%$; and (iii) cost-to-income ratio increases the gearing ratio by $3.3 \%-4.4 \%$. Column (2) also offers some evidence that larger projects are less leveraged. Sector-fixed effects in column (1) show cross-sector heterogeneity in average gearing ratios as in (i) $29.96 \%$ for mining, oil, and gas; (ii) $33.03 \%$ for industry sector; (iii) $36.02 \%$ for transport; and (iv) 38.39\% for energy. Projects outside these sectors are more leveraged with an average gearing ratio of $45.91 \% .{ }^{15}$ All sector-fixed effects are significant at the $5 \%$ level. Sector-fixed effects in column (2) line up consistently with those reported in column (1), whereby projects in mining, oil, and gas are the least leveraged (55.70\%), and those in other sectors are the most leveraged $(71.77 \%)$.

The analysis proceeds in assessing the robustness of these results to the inclusion of time trends common to project financing in all countries, as well as country-specific variables. In columns (3)-(4), quarter-fixed effects are incorporated to the specifications in columns (1)-(2). Point estimates and their significance are consistent with those in the first two columns. In columns (5)-(6), time-varying proxies for economic and institutional conditions are further included, together with country-fixed effects. As far as the country variables are concerned, results show that the gearing ratio depends positively on GDP per capita, which certifies that project finance tends to be higher in larger markets where demand and purchasing power are higher, following Hammami, Ruhashyankiko, and Yehoue (2006). In addition, the regression results uncover a negative dependence between the gearing ratio and government indebtedness which may proxy for sovereign default risk, and banks may be unwilling to provide long-term funding under these conditions. Moreover, gearing ratios are positively associated with inflation risk (proxy by the volatility of inflation rates), while these are unaffected by both economic and currency risks. Initially, this evidence may be counterintuitive as being long-term investments, project finance investments are highly exposed to inflation risk. Thus, one would expect gearing ratios and inflation risk to be negatively (rather than positively) related. Two explanations are offered for this result. First, it may well be that interest rates on project finance debt are

14 Clustering standard errors at the syndicate level implies that correlation of the error term(s) within a syndicate is controlled, which is the level at which the variables or interests are observed. Thus, the possibility that projects (error terms of our projects) are not independently and identically distributed within the same syndicate due to omitted variables at the syndicate level is effectively accounted for.

15 Sector-fixed effects are estimated from model specifications without the constant term. 
floating or inflation-indexed, in which case inflation risk gets mitigated. Second, anecdotal evidence says that many project finance transactions are exposed to inflation, both on the revenues and the operational cost side, which implies a natural hedge against inflation. Since there is lack of information on loan rates or project profit and loss structure, this reasoning is only suggestive. Further, results show no evidence that political stability and institutional quality affects debt investment in project-finance deals. One possible explanation is that the governance indicators employed exhibit limited time variation, at the country level and, therefore, country-fixed effects absorb much of the cross-country variation. ${ }^{16}$

The introduction of country variables gives a different picture about the relevance of syndicates' balance sheet. The tier 1 ratio continues to be positively associated with the project gearing ratio, and with a relatively stable coefficient. Liquid assets and cost-to-income, however, are no longer statistically significant. Since most projects are funded by local banks, this suggests that asset liquidity and cost efficiency tend to move more together with the economic conditions of the local economy. Columns (5)-(6) are also suggestive that banks with a larger loan portfolio provide less funds to project finance deals. As far as the economic magnitude of this effect is concerned, a one-standard deviation increase in loans-to-assets decreases the gearing ratio by $3.1 \%-3.2 \%$. Overall, no projectlevel variable appears to be a driver of the gearing ratio at standard significance levels.

The lower part of Table 7 reports the R-squared decomposition for the groups of variables (Shapley values). There is a substantial portion of gearing ratios that country, project, and syndicate characteristics are unable to explain, since quarter fixed effects account for about one third of the variability in gearing ratios for the most complete specification. On the other hand, sector-fixed effects do not appear to be very important. Overall, the financing structure of the sample projects depends substantially on both observable and unobservable country characteristics. Bank balance sheets constitute the third most important source of variation in project finance gearing ratios, and contribute about $17 \%$ to the overall $\mathrm{R}$-squared.

Table 7: Drivers of Project-Finance Deals

\begin{tabular}{|c|c|c|c|c|c|c|c|}
\hline Variable & Characteristic & (1) & (2) & (3) & (4) & (5) & (6) \\
\hline Tier 1 & Syndicate & $\begin{array}{l}1.273^{* * *} \\
(0.349)\end{array}$ & $\begin{array}{l}1.056^{* * *} \\
(0.327)\end{array}$ & $\begin{array}{l}1.289^{* * *} \\
(0.444)\end{array}$ & $\begin{array}{l}1.187^{* * *} \\
(0.438)\end{array}$ & $\begin{array}{l}1.094^{* * *} \\
(0.380)\end{array}$ & $\begin{array}{l}1.060^{* * *} \\
(0.407)\end{array}$ \\
\hline \multirow[t]{2}{*}{ ROAA } & Syndicate & 2.009 & -0.054 & 0.906 & -1.382 & -2.981 & $-4.525^{*}$ \\
\hline & & $(3.090)$ & $(3.049)$ & $(2.700)$ & $(2.774)$ & $(2.460)$ & $(2.595)$ \\
\hline \multirow[t]{2}{*}{ Loans } & Syndicate & 0.077 & 0.058 & 0.049 & 0.016 & $-0.416^{*}$ & $-0.401^{*}$ \\
\hline & & $(0.215)$ & $(0.199)$ & $(0.210)$ & $(0.192)$ & $(0.212)$ & $(0.218)$ \\
\hline \multirow[t]{2}{*}{ NPL } & Syndicate & -1.289 & -1.334 & -1.224 & -1.373 & -1.139 & -1.435 \\
\hline & & $(1.040)$ & $(0.980)$ & $(1.001)$ & $(0.950)$ & $(0.960)$ & $(1.017)$ \\
\hline \multirow[t]{2}{*}{ Liquid assets } & Syndicate & $0.753^{* * *}$ & $0.653^{* * *}$ & $0.791^{* *}$ & $0.737^{* * *}$ & 0.323 & 0.363 \\
\hline & & $(0.279)$ & $(0.239)$ & $(0.320)$ & $(0.278)$ & $(0.345)$ & $(0.342)$ \\
\hline \multirow[t]{2}{*}{ Cost-to-income ratio } & Syndicate & $0.334^{* * *}$ & $0.246^{* *}$ & $0.311^{* * *}$ & $0.227^{* *}$ & 0.063 & 0.067 \\
\hline & & (0.103) & $(0.112)$ & $(0.106)$ & $(0.105)$ & $(0.130)$ & $(0.130)$ \\
\hline \multirow[t]{2}{*}{ Ln (syndicate size) } & Syndicate & -1.743 & -0.009 & -1.038 & 0.575 & -1.042 & -0.574 \\
\hline & & $(2.194)$ & $(1.936)$ & $(2.121)$ & $(1.988)$ & $(2.367)$ & $(2.170)$ \\
\hline
\end{tabular}

16 To address the problem of limited variation in the governance indicators in the country variables, two sets of regressions are conducted: one without country-level variables (time-varying, albeit with limited variation, as well as time-invariant), and one with the abovementioned. Moreover, wherever possible, country-level variables at the quarterly frequency are used to gain more variation over time. 
An Empirical Analysis of the Factors that Influence Infrastructure Project Financing by Banks in Select Asian Economies | 15

Table 7 continued

\begin{tabular}{|c|c|c|c|c|c|c|c|}
\hline Variable & Characteristic & (1) & (2) & (3) & (4) & (5) & (6) \\
\hline MDB & Syndicate & $\begin{array}{c}-7.243^{*} \\
(3.838)\end{array}$ & $\begin{array}{r}-4.456 \\
(3.564)\end{array}$ & $\begin{array}{r}-6.360 \\
(4.394)\end{array}$ & $\begin{array}{l}-5.043 \\
(4.147)\end{array}$ & $\begin{array}{c}-9.317^{* *} \\
(4.563)\end{array}$ & $\begin{array}{l}-6.883 \\
(4.734)\end{array}$ \\
\hline \multirow[t]{2}{*}{ Local bank } & Syndicate & 7.584 & 7.800 & $10.162^{*}$ & $10.903^{*}$ & 6.574 & 10.648 \\
\hline & & $(5.317)$ & $(5.279)$ & $(6.070)$ & $(6.315)$ & $(7.098)$ & $(7.784)$ \\
\hline \multirow[t]{2}{*}{$\operatorname{Ln}(\cos t)$} & Project & & $-2.617^{* * *}$ & & $-2.119^{* * *}$ & & -0.454 \\
\hline & & & $(0.657)$ & & $(0.771)$ & & $(0.626)$ \\
\hline \multirow[t]{2}{*}{$\operatorname{Ln}$ (maturity) } & Project & & -1.057 & & -2.114 & & $-4.078^{*}$ \\
\hline & & & $(2.444)$ & & $(2.223)$ & & $(2.104)$ \\
\hline \multirow[t]{2}{*}{ Ln (tranches) } & Project & & -1.871 & & 0.252 & & -3.352 \\
\hline & & & $(3.873)$ & & $(3.127)$ & & $(3.043)$ \\
\hline \multirow[t]{2}{*}{ Foreign currency } & Project & & 2.018 & & 0.296 & & 2.955 \\
\hline & & & $(3.132)$ & & $(3.512)$ & & $(3.460)$ \\
\hline \multirow[t]{2}{*}{ GDP } & Country & & & & & $1.229^{* *}$ & $1.171^{* *}$ \\
\hline & & & & & & $(0.502)$ & $(0.484)$ \\
\hline \multirow[t]{2}{*}{ Inflation } & Country & & & & & 0.574 & 0.668 \\
\hline & & & & & & $(0.758)$ & $(0.709)$ \\
\hline \multirow[t]{2}{*}{ Gov't debt } & Country & & & & & $-2.180^{*}$ & $-2.114^{*}$ \\
\hline & & & & & & $(1.195)$ & $(1.247)$ \\
\hline \multirow[t]{2}{*}{$\mathrm{VOL}(\mathrm{GDP})$} & Country & & & & & -3.623 & -2.852 \\
\hline & & & & & & $(3.203)$ & $(2.966)$ \\
\hline \multirow[t]{2}{*}{ VOL (Inflation) } & Country & & & & & $9.056^{* * *}$ & $9.192^{* *}$ \\
\hline & & & & & & $(3.300)$ & (3.587) \\
\hline \multirow[t]{2}{*}{ VOL (exchange rate) } & Country & & & & & 183.321 & 304.276 \\
\hline & & & & & & $(285.694)$ & $(294.645)$ \\
\hline \multirow[t]{2}{*}{ PPP investment } & Country & & & & & 4.840 & 3.809 \\
\hline & & & & & & $(3.457)$ & $(3.288)$ \\
\hline \multirow[t]{2}{*}{ Political stability } & Country & & & & & -12.449 & -14.513 \\
\hline & & & & & & $(13.122)$ & $(13.064)$ \\
\hline \multirow[t]{2}{*}{ Regulatory quality } & Country & & & & & 35.627 & 43.783 \\
\hline & & & & & & $(30.585)$ & (29.708) \\
\hline Sector FE & Country & Yes & Yes & Yes & Yes & Yes & Yes \\
\hline Quarter FE & Country & No & No & Yes & Yes & Yes & Yes \\
\hline Country FE & Country & No & No & No & No & Yes & Yes \\
\hline Observations & Country & 244 & 244 & 244 & 244 & 244 & 244 \\
\hline Adjusted R-squared & Country & 0.192 & 0.231 & 0.271 & 0.294 & 0.399 & 0.404 \\
\hline \multicolumn{8}{|c|}{ Shapley values for R-squared decomposition, $\%$} \\
\hline Syndicate characteristics & Country & 69.56 & 45.15 & 38.14 & 29.00 & 19.39 & 16.68 \\
\hline Project characteristics & Country & & 35.09 & & 20.94 & & 10.90 \\
\hline Country characteristics & Country & & & & & 21.43 & 19.03 \\
\hline Sector FE & Country & 30.44 & 19.75 & 19.12 & 14.09 & 9.05 & 8.41 \\
\hline Quarter FE & Country & & & 42.74 & 35.96 & 31.89 & 29.29 \\
\hline Country FE & Country & & & & & 18.25 & 15.69 \\
\hline
\end{tabular}

$\mathrm{FE}=$ fixed effects, $\mathrm{GDP}=$ gross domestic product, $\mathrm{LN}=$ natural logarithm, $\mathrm{MDB}=$ multilateral development banks, $N P L=$ nonperforming loan, $\mathrm{PPP}=$ public-private partnership, $\mathrm{ROAA}$ = return on average assets, $\mathrm{VOL}=$ volatility.

Note: Table 7 presents ordinary least squares regression results to examine the drivers of project finance deals. The sample includes 244 projects financed between 2011 and 2016 in India, Indonesia, Malaysia, the Philippines, the Republic of Korea, Thailand, and Viet Nam. The dependent variable is the gearing ratio. Standard errors are clustered at the syndicate level. ${ }^{* * *}{ }^{* *}$, and ${ }^{*}$ denote statistical significance at $1 \%, 5 \%$, and $10 \%$ levels, respectively.

Source: Author's estimates. 


\section{A. Policy Implications}

Overall, the evidence seems to indicate that the volume of debt financing in the countries under examination is driven more by the country macroeconomic variables (GDP per capita and gross debtGDP ratio) rather than by other macro variables related to institutional quality and by the microeconomic variables referred to project characteristics. This result is probably due to the still early stage adoption compared with advanced economies of structured finance techniques in these economies. Banks appear to be comfortable in lending to infrastructure within PPP/project financing schemes in emerging economies, particularly in the case of large financial institutions, only if the country reaches minimum acceptable conditions in terms of growth and a reasonable risk profile in terms of total debt over GDP. In this sense, the insignificance of project variables indicates that banks do not discriminate among projects belonging to different sectors, if the country shows a sufficiently good set of macroeconomic variables. From a policy perspective, results imply that attracting private financing for infrastructure PPP projects through project finance is dependent on policies for sustaining country growth.

A special comment must be given to bank-specific variables. While the coefficient of tier 1 ratio is positive and strongly significant in all the model specifications, the results indicate a weak evidence of a negative relation between the projects' gearing ratio and the ratio of loans to total assets. While these results are interpreted as evidence of the fact that well-capitalized arrangers are in a better position to invest more debt in infrastructure projects, it also appears that project finance is a substitute for other lending activities. In fact, a negative coefficient of the loans-to-asset ratio tells that the bigger the bank loan portfolio, the lower the gearing ratio is for Asian infrastructure PPP projects. The overall evidence corroborates the view of policymakers that see actions to strengthen the banks' capital base under Basel III standards and, in the longer term, Solvency II for nonbank intermediaries as a fundamental to expanding lending (Gatti 2013 and OECD 2014).

The dominant literature on the topic suggests that strong institutions and an appropriate and dedicated legal framework may be crucial for the development of PPP (Vecchi, Airoldi, and Caselli 2015). However, it must be underlined that the scope of this paper to analyze the role of nonfinancial contracts in the context of project finance in Asia is constrained by the paucity of data. Accordingly, the phase in which the project is structured (project planning, contract tender, and negotiation and award) is not considered, but rather the successive step, once the project has been awarded and the contract between the public and the private parties has been signed.

\section{B. Comparative Analysis}

An identical analysis was conducted using data from advanced PPP markets including Australia, Canada, and the United Kingdom. While the comparison is only notional as these countries use a design, build, finance, and operate (DBFO) availability based PPP agreement which is different from the standard PPP contract used in Asia, it does provide some perspective on the results obtained from analyzing Asian PPP markets. Taken as a whole, the analysis of the said mature PPP markets indicates that project-related variables have greater explanatory power than in Asian markets, suggesting that the project finance modality is more entrenched therein. With regard to bank syndicate variables, while capital does not explain bank lending, bank profitability, and the extent of impaired assets have limited explanatory power. This may be attributable to the quicker implementation of Basel III capital standards in countries where the syndicated banks that lend to PPP projects in Australia, Canada, and the United Kingdom are headquartered, rendering them with a stronger capital base. 


\section{CONCLUSIONS AND DIRECTIONS FOR FUTURE RESEARCH}

The paper provides guidance on the role of banks in financing infrastructure in Asia through project finance deals. The implications of findings are that, at the current state of the market, it is more the macroeconomic risk factors and the strength of bank balance sheets that are the key determinants of bank exposure to PPP projects in the Asian markets. In this context, it appears that banks are agnostic among projects belonging to different sectors, if the country shows a sufficiently good set of macroeconomic variables. This evidence is corroborated by the analysis of advanced PPP markets where project financing norms have gained more traction and acceptability, and where project transactions variables are indeed significant.

The key findings of this paper with respect to Asian markets have significant implications in the development of an enabling framework for the PPP modality. In this context, the role of project finance in promoting PPP arrangements is crucial in that the project finance technique promotes risk transfer and optimal risk allocation among PPP stakeholders. Several sources, including the Organisation for Economic Co-operation and Development (OECD) (2014), indicate that the evolution of project finance lending will be based more on a direct role of debt capital markets rather than on more traditional bank lending, in both advanced and developed economies. The servicing of bank debt solely through SPV-specific cash flows results in a higher credit spread, thus incentivizing project companies to seek alternative sources of finance, such as via capital market instruments, and to retire bank loans. Thus, the role of banks will be limited to financing the initial construction phase.

This trend is expected to be strengthened as banks move towards Basel III capital standards, suggested by the notional comparison between Asian and mature PPP markets. Various sources estimate that the banks' funding costs are likely to increase by 60-110 basis points and empirical estimates indicate that the availability of project loans for over 10-year maturity will also likely to significantly reduce (Ma 2016). The reduction in the tenor of bank financing also has further implications on the credit spread as shorter tenors can put additional liquidity pressure in project SPVs before operations stabilize (Sorge and Gadanecz 2004). Accordingly, project companies will be further incentivized to seek out capital market instruments to reduce funding costs and extend debt maturities. The current state of debt capital markets, with a large pool of liquid resources available, coupled with record low levels of interest rates, is a context that makes this search quicker and easier.

While SPVs will be incentivized to explore capital market instruments with Basel III norms kicking in, several authors including Corielli, Gatti, and Steffanoni (2010) and Subramanian and Tung (2016) have observed that project finance is a nexus of contracts, the quality of which have implications on volume and pricing of project finance deals. The quality of contracts and the optimality of risk allocation achieved through them is a determining factor in attracting investors into projectspecific capital market instruments, especially as bond investors are far removed from projects and do not have direct project monitoring capacity such as banks. ${ }^{17}$ Accordingly, a careful examination of the key contracts underpinning each project finance deals, together with a more detailed analysis of PPP regulations at the country level, would enable a better understanding of the determinants of infrastructure financing in Asia. This would also provide more specific guidance on institutional,

17 Another clear trend emerging in the debt capital markets for project finance transactions is the development of various forms of partnerships between traditional bank lenders and institutional investors, where banks provide know-how in screening and monitoring the projects and play a delegated monitoring role on behalf of institutional investors joining the partnership (OECD 2014). 
regulatory, and governance gaps that will need to be filled to enable project SPVs to access the capital market.

An additional area of research and one that is assuming increasing importance is the role of guarantees in catalyzing finance, both through banks and bonds. Following Vecchi et al. (2017), of interest is the role of commercially provided guarantees that reduces project risk while maintaining the essential feature of project finance and not encouraging moral hazard by banks. There is a paucity of data on guarantees in project finance transactions in Asia and the role of guarantees in achieving financial close of projects. Several markets have unmitigated risk factors with respect to project delays, and these have significant impact on cost and availability of debt. A focused research on the role of guarantees will shed light on targeting and pricing of these instruments to expand financing options. 


\section{APPENDIX}

Table A1 provides descriptive statistics (project and syndicate characteristics) for the data obtained from the sample of 173 projects financed between 2011 and 2016 in Australia, Canada, and the United Kingdom. The last two columns of the table present test statistics for the t-test and the Wilcoxon test of the differences in project characteristics between the two samples.

The data indicate that projects in these markets are of larger size and are more leveraged. Further, projects have shorter maturity, involve more debt tranches, and are financed more in local currencies. In addition, projects are financed by larger syndicates, and witness less participation of local banks. Finally, banks funding projects are more capitalized, have more nonperforming loans, have more liquid assets, are less profitable, less efficient, and have fewer loans on their balance sheets.

\section{Table A1: Project Level Descriptive Statistics (Mature Markets)}

\begin{tabular}{lrrrrrr}
\hline & & & & & \multicolumn{2}{c}{ Test of Differences } \\
\cline { 6 - 7 } Variable & Mean & \multicolumn{1}{c}{$\mathrm{p} 50$} & \multicolumn{1}{c}{$\mathrm{p} 5$} & $\mathrm{p} 95$ & $\mathrm{t}$-test & Wilcoxon \\
\hline Gearing & 90.01 & 100.00 & 60.00 & 100.00 & $2.158^{* *}$ & $2.111^{* *}$ \\
Cost & 481.90 & 184.10 & 34.00 & 2135.60 & $1.914^{* *}$ & $4.289^{* * *}$ \\
Maturity (equally & 11.78 & 8.99 & 2.00 & 26.02 & $-1.796^{*}$ & $-3.083^{* * *}$ \\
$\quad$ weighted) & & & & & & \\
Tranches & 1.65 & 1.00 & 1.00 & 3.00 & $1.828^{*}$ & $2.279^{* *}$ \\
Local currency & 0.87 & 1.00 & 0.00 & 1.00 & $3.362^{* * *}$ & $3.180^{* * *}$ \\
Foreign currency & 0.13 & 0.00 & 0.00 & 1.00 & $-3.362^{* * *}$ & $-3.180^{* * *}$ \\
Syndicate size & 3.60 & 2.00 & 1.00 & 10.00 & $5.416^{* * *}$ & $6.682^{* * *}$ \\
MDB & 0.16 & 0.00 & 0.00 & 1.00 & 1.585 & 1.631 \\
Local bank & 0.22 & 0.00 & 0.00 & 1.00 & $-19.359^{* * *}$ & $-13.820^{* * *}$ \\
Tier 1 & 13.30 & 12.90 & 10.60 & 18.00 & $5.258^{* * *}$ & $6.252^{* * *}$ \\
ROAA & 0.37 & 0.35 & -0.18 & 1.05 & $-15.736^{* * *}$ & $-13.137^{* * *}$ \\
Loans & 48.27 & 50.44 & 24.34 & 70.61 & $-8.624^{* * *}$ & $-8.696^{* * *}$ \\
Nonperforming loan & 3.79 & 2.80 & 0.75 & 8.10 & $4.372^{* * *}$ & $2.806^{* * *}$ \\
Liquid assets & 22.49 & 21.75 & 11.07 & 45.11 & $14.470^{* * *}$ & $13.044^{* * *}$ \\
Cost/income & 62.94 & 61.87 & 45.17 & 88.56 & $7.089^{* * *}$ & $8.182^{* * *}$ \\
\hline
\end{tabular}

$\mathrm{MDB}=$ multilateral development bank, $\mathrm{ROAA}=$ return on average assets.

Note: ${ }^{* * *},{ }^{* *}$, and ${ }^{*}$ denote statistical significance at $1 \%, 5 \%$, and $10 \%$ levels, respectively.

Source: Authors estimates based on Thomson One Banker.

Regarding model estimation, syndicate's overall balance sheet characteristics are, not very important. Table A2 shows some weak evidence that more profitable banks (column [2]) and more troubled banks (ratio of impaired to total loans, columns [3] and [5]) are more likely to lend. One explanation is that syndicates that fund projects in the mature PPP markets are based in countries where the quicker implementation of Basel III rules have rendered them stronger from the capital base standpoint, than what is observed in Asian syndicates. Syndicates' composition are classified by the degree of compliance with Basel III standard of the countries where banks are headquartered. Banks financing projects in Asian countries (largely local banks) are based in countries that are not yet compliant with Basel III regulation. 
Further, the analysis indicates that, in mature markets, project characteristics are more important. In particular, gearing is negatively associated to project size and positively associated to project duration. The evidence is in accordance with the view that the project finance modality is more entrenched in mature markets and bank lending is transaction-based. As far as macro variables are concerned, consistent with the analysis in Asian markets, the results show a negative dependence of gearing ratios on government indebtedness. However, different from Table 7 in the main text, inflation as well as inflation risk now negatively affect project finance investment.

Table A2: Drivers of Project Finance Deals (Mature Markets)

\begin{tabular}{|c|c|c|c|c|c|c|c|}
\hline Variable & Characteristic & (1) & (2) & (3) & (4) & (5) & (6) \\
\hline \multirow[t]{2}{*}{ Tier 1} & Syndicate & 0.305 & 0.074 & 0.061 & -0.315 & -0.346 & -0.661 \\
\hline & & $(0.529)$ & $(0.531)$ & $(0.692)$ & $(0.636)$ & $(0.744)$ & $(0.675)$ \\
\hline \multirow[t]{2}{*}{ ROAA } & Syndicate & 5.421 & $7.194^{*}$ & 5.893 & 7.721 & 6.297 & 5.576 \\
\hline & & $(4.909)$ & $(4.211)$ & $(5.106)$ & $(4.882)$ & $(5.531)$ & $(4.914)$ \\
\hline \multirow[t]{2}{*}{ Loans } & Syndicate & 0.069 & 0.072 & -0.020 & -0.015 & 0.036 & -0.030 \\
\hline & & $(0.152)$ & $(0.144)$ & $(0.169)$ & $(0.144)$ & $(0.178)$ & $(0.155)$ \\
\hline \multirow[t]{2}{*}{ NPL } & Syndicate & 0.832 & 0.555 & $0.999^{*}$ & 0.796 & $1.288^{*}$ & 1.248 \\
\hline & & $(0.561)$ & $(0.571)$ & $(0.573)$ & $(0.562)$ & $(0.776)$ & $(0.764)$ \\
\hline \multirow[t]{2}{*}{ Liquid assets } & Syndicate & 0.024 & -0.016 & -0.122 & -0.129 & -0.175 & -0.125 \\
\hline & & $(0.177)$ & $(0.145)$ & $(0.183)$ & $(0.154)$ & $(0.201)$ & $(0.188)$ \\
\hline \multirow[t]{2}{*}{ Cost-to-income ratio } & Syndicate & -0.052 & 0.136 & 0.013 & 0.216 & 0.008 & 0.158 \\
\hline & & $(0.210)$ & $(0.226)$ & $(0.232)$ & $(0.224)$ & $(0.257)$ & $(0.249)$ \\
\hline \multirow[t]{2}{*}{ Ln (syndicate size) } & Syndicate & -2.071 & 5.076 & -1.386 & $6.180^{* *}$ & -0.523 & $6.189^{* *}$ \\
\hline & & $(1.795)$ & (3.227) & $(1.868)$ & $(2.946)$ & $(1.927)$ & $(2.882)$ \\
\hline \multirow[t]{2}{*}{ MDB } & Syndicate & -2.155 & -1.526 & -1.362 & -0.744 & -2.542 & -1.352 \\
\hline & & (3.704) & $(3.142)$ & $(4.084)$ & (3.433) & $(4.017)$ & $(3.044)$ \\
\hline \multirow[t]{2}{*}{ Local bank } & Syndicate & -6.177 & -4.921 & 0.009 & 2.347 & -3.054 & 1.185 \\
\hline & & $(4.123)$ & $(4.146)$ & (5.144) & $(4.845)$ & (4.977) & $(4.771)$ \\
\hline \multirow[t]{2}{*}{$\operatorname{Ln}(\cos t)$} & Project & & $-6.112^{* * *}$ & & $-6.478^{* * *}$ & & $-6.059^{* * *}$ \\
\hline & & & $(2.124)$ & & (1.950) & & (1.778) \\
\hline \multirow[t]{2}{*}{ Ln (maturity) } & Project & & $3.888^{* * *}$ & & $4.397^{* * *}$ & & $5.299^{* * *}$ \\
\hline & & & $(1.466)$ & & $(1.553)$ & & $(1.610)$ \\
\hline \multirow[t]{2}{*}{ Ln (tranches) } & Project & & -1.030 & & -1.703 & & -1.470 \\
\hline & & & $(2.317)$ & & $(2.424)$ & & $(2.525)$ \\
\hline \multirow[t]{2}{*}{ Foreign currency } & Project & & 3.581 & & 2.667 & & 4.172 \\
\hline & & & $(2.861)$ & & (3.068) & & $(3.607)$ \\
\hline \multirow[t]{2}{*}{ GDP } & Country & & & & & -1.168 & -1.781 \\
\hline & & & & & & (3.955) & (3.434) \\
\hline \multirow[t]{2}{*}{ Inflation } & Country & & & & & $-9.741^{* *}$ & $-11.237^{* *}$ \\
\hline & & & & & & $(4.820)$ & (4.599) \\
\hline \multirow[t]{2}{*}{ Government debt } & Country & & & & & $-5.336^{* *}$ & $-5.980^{* * *}$ \\
\hline & & & & & & $(2.538)$ & $(2.224)$ \\
\hline \multirow[t]{2}{*}{ VOL (GDP) } & Country & & & & & 2.379 & 0.152 \\
\hline & & & & & & $(8.471)$ & (7.378) \\
\hline \multirow[t]{2}{*}{ VOL (Inflation) } & Country & & & & & $-57.267^{* *}$ & $-62.933^{* *}$ \\
\hline & & & & & & $(27.934)$ & $(24.170)$ \\
\hline \multirow[t]{2}{*}{ VOL (Exchange rate) } & Country & & & & & -88.768 & -578.378 \\
\hline & & & & & & $(583.126)$ & (510.647) \\
\hline
\end{tabular}


Table A2 continued

\begin{tabular}{lccrrrrr}
\hline Variable & Characteristic & $(1)$ & $(2)$ & $(3)$ & $(4)$ & \multicolumn{1}{c}{$(5)$} & \multicolumn{1}{c}{$(6)$} \\
\hline PPP Investment & Country & & & & & 7.920 & 5.856 \\
& & & & & $(5.140)$ & $(4.396)$ \\
Political stability & Country & & & & & 61.947 & 56.247 \\
& & & & & & $(37.928)$ & $(38.372)$ \\
Regulatory quality & Country & & & & & -17.738 & -38.839 \\
& & & & & & $(53.789)$ & $(48.840)$ \\
\hline Sector FE & Country & Yes & Yes & Yes & Yes & Yes & Yes \\
Quarter FE & Country & No & No & Yes & Yes & Yes & Yes \\
Country FE & Country & No & No & No & No & Yes & Yes \\
Observations & Country & 173 & 173 & 173 & 173 & 173 & 173 \\
Adjusted R-squared & Country & 0.004 & 0.163 & $(0.015)$ & 0.174 & 0.107 & 0.266 \\
\hline Shapley values for R-squared decomposition, $\%$ & & & & & & \\
Syndicate characteristics & Country & 60.10 & 16.95 & 18.93 & 10.45 & 13.76 & 8.79 \\
Project characteristics & Country & & 73.56 & & 46.48 & & 30.11 \\
Country characteristics & Country & & & & & 33.07 & 22.47 \\
Sector FE & Country & 39.90 & 9.49 & 13.80 & 5.37 & 6.63 & 3.98 \\
Quarter FE & Country & & & 67.27 & 37.69 & 37.86 & 28.67 \\
Country FE & Country & & & & & 8.68 & 5.89 \\
\hline
\end{tabular}

$\mathrm{FE}=$ fixed effects, GDP = gross domestic product, $\mathrm{LN}=$ natural logarithm, MDB = multilateral development bank, NPL = nonperforming loan, $\mathrm{PPP}=$ public-private partnership, $\mathrm{ROAA}=$ return on average assets, $\mathrm{VOL}=$ volatility.

Notes: This table presents ordinary least squares regression results to examine the drivers of project-finance deals. The sample includes 173 projects financed between 2011 and 2016 in Australia, Canada, and the United Kingdom. The dependent variable is the gearing ratio. Definitions of the explanatory variables are provided in Table A3. Standard errors are clustered at the syndicate level. ${ }^{* *},{ }^{* *}$, and ${ }^{*}$ denote statistical significance at the 1\%,5\%, and 10\% levels, respectively. Sector fixed effects for columns (1) and (2) show gearing ratios at their lowest for other sectors, and at their highest for either energy (column [1]) or transport (column [2]).

Source: Author's estimates. 
Table A3: Sources and Description of Variables

\begin{tabular}{|c|c|c|c|}
\hline Variable & Description & Characteristic, Units & Source \\
\hline Gearing & Gearing ratio (debt over cost) & Project, \% & Thomson One Banker \\
\hline $\begin{array}{l}\text { Gross domestic } \\
\text { product (GDP) }\end{array}$ & $\begin{array}{l}\text { Real GDP per capita, year-on-year } \\
\text { change }\end{array}$ & Country-quarter, $\%$ & Datastream \\
\hline Inflation & $\begin{array}{l}\text { CPI seasonally adjusted, year-on } \\
\text { year change }\end{array}$ & Country-quarter, $\%$ & Datastream \\
\hline Government debt & $\begin{array}{l}\text { General government gross debt, } \% \\
\text { of GDP }\end{array}$ & Country-year, $\%$ & Datastream \\
\hline VOL (GDP) & $\begin{array}{l}\text { Rolling standard deviation of GDP } \\
\text { ( } 5 \text { previous years and current } \\
\text { quarter) }\end{array}$ & Country-quarter, $\%$ & CEIC, ARIC \\
\hline VOL (Inflation) & $\begin{array}{l}\text { Rolling standard deviation of } \\
\text { Inflation ( } 5 \text { previous years and } \\
\text { current quarter) }\end{array}$ & Country-quarter, $\%$ & CEIC, ARIC \\
\hline VOL (Exchange rate) & $\begin{array}{l}\text { Rolling standard deviation of log } \\
\text { changes in local currency/US dollar } \\
\text { exchange rate ( } 5 \text { previous years } \\
\text { and current quarter) }\end{array}$ & Country-quarter, $\%$ & CEIC, ARIC \\
\hline PPP investment & Investment in PPP, $\%$ of GDP & Country-year, \% & $\begin{array}{l}\text { World Bank, Private } \\
\text { Participation in } \\
\text { Infrastructure database }\end{array}$ \\
\hline Political stability & $\begin{array}{l}\text { Political stability and absence of } \\
\text { violence (estimate), lagged year }\end{array}$ & Country-year, range $[-2.5,2.5]$ & $\begin{array}{l}\text { World Bank, World } \\
\text { Governance Indicators } \\
2016\end{array}$ \\
\hline Regulatory quality & $\begin{array}{l}\text { Regulatory quality (estimate), } \\
\text { lagged year }\end{array}$ & Country-year, range $[-2.5,2.5]$ & $\begin{array}{l}\text { World Bank, World } \\
\text { Governance Indicators } \\
2016\end{array}$ \\
\hline Cost & Total cost & Project, $\$$ million & Thomson One Banker \\
\hline Maturity & $\begin{array}{l}\text { Average maturity across term loans } \\
\text { (equal weighting) }\end{array}$ & Project, years & Thomson One Banker \\
\hline Tranches & Number of term loans tranches & Project, range $[1,6]$ (interest) & Thomson One Banker \\
\hline Foreign currency & $\begin{array}{l}=1 \text { when at least one term loan is } \\
\text { denominated in foreign currency }\end{array}$ & Project, dummy & Thomson One Banker \\
\hline Syndicate size & Number of mandated arrangers & $\begin{array}{l}\text { Syndicate, range }[1,25] \\
\text { (interest) }\end{array}$ & Thomson One Banker \\
\hline MDB & $\begin{array}{l}=1 \text { when at least one mandated } \\
\text { arranger is a multilateral } \\
\text { development bank }\end{array}$ & Syndicate, dummy & Thomson One Banker \\
\hline Local bank & $\begin{array}{l}\text { Fraction of mandated arrangers } \\
\text { (over syndicate size) } \\
\text { headquartered in the same country } \\
\text { of the project }\end{array}$ & Syndicate, range $[0,1]$ & $\begin{array}{l}\text { Thomson One Banker, } \\
\text { BvD Orbis }\end{array}$ \\
\hline Tier 1 & Tier 1 ratio & Syndicate & BvD Orbis \\
\hline ROAA & ROAA & Syndicate & BvD Orbis \\
\hline Loans & Net loans over total assets & Syndicate & BvD Orbis \\
\hline Nonperforming loan & Impaired over gross loans & Syndicate & BvD Orbis \\
\hline Liquid assets & Liquid over total assets & Syndicate & BvD Orbis \\
\hline Cost/Income & Cost to income ratio & Syndicate & BvD Orbis \\
\hline
\end{tabular}

$\mathrm{ARIC}=$ Asia Regional Integration Center, $\mathrm{CEIC}=\mathrm{CEIC}$ Data Company Limited, $\mathrm{CPI}=$ consumer price index, $\mathrm{MDB}=$ multilateral development bank, $\mathrm{PPP}$ = public-private partnership, $\mathrm{ROAA}$ = return on average assets, $\mathrm{VOL}$ = volatility.

Sources: See sources column. 


\section{REFERENCES}

Acemoglu, Daron, Simon Johnson, James Robinson, and Yunyong Thaicharoen. 2003. "Institutional Causes, Macroeconomic |Symptoms: Volatility, Crises and Growth.” Journal of Monetary Economics 50 (1): pp. 49-123.

Asian Development Bank (ADB). 2017. Meeting Asia's Infrastructure Needs. Manila.

Bernanke, Ben, and Mark Gertler. 1988. "Credit, Money, and Aggregate Demand." American Economic Review 78 (2): 435-39.

_. 1995. "Inside the Black Box: The Credit Channel of Monetary Policy Transmission." Journal of Economic Perspectives 9 (4): 27-48. doi:10.1257/jep.9.4.27.

Blanc-Brude, Frédéric, Hugh Goldsmith, and Timo Välilä. 2006. "Ex-Ante Construction Costs in the European Road Sector: A Comparison of Public-Private Partnerships and Traditional Public Procurement." EIB Economic and Financial Report No. 2006/01. https://ssrn.com/abstract=1104070.

Borio, Claudio, and Haibin Zhu. 2008. "Capital Regulation, Risk-Taking and Monetary Policy: A Missing Link in the Transmission Mechanism?" BIS Working Papers No. 268. https://www.bis.org/publ/work268.pdf.

Brealey, Richard A., lan A. Cooper, and Michel A. Habib. 1996. "Using Project Finance to Fund Infrastructure Investments." Journal of Applied Corporate Finance 9 (3): 25-39.

Clark, Peter, Natalia Tamirisa, Shang-Jin Wei, Azim Sadikov, and Li Zeng. 2004. "A New Look at Exchange Rate Volatility and Trade Flows." IMF Occasional Paper 235.

Corielli, Francesco, Stefano Gatti, and Alessandro Steffanoni. 2010. "Risk Shifting through Nonfinancial Contracts: Effects on Loan Spreads and Capital Structure on Project Finance Deals." Journal of Money, Credit and Banking 42 (7): 1295-320.

Diamond, Douglas. 1984. "Financial Intermediation and Delegated Monitoring." Review of Economic Studies 51 (3): 393-414.

Disyatat, Piti. 2010. "The Bank Lending Channel Revisited." BIS Working Papers No. 297. https://www.bis.org/publ/work297.pdf.

Esty, Benjamin C. 2001. "Structuring Loan Syndicates: A Case Study of the Hong Kong Disneyland Project Loan." Journal of Applied Corporate Finance 14 (3): 80-95.

—. 2004. "Why Study Large Projects? An Introduction to Research on Project Finance." European Financial Management 10 (2): 213-24.

Esty, Benjamin C., and William L. Megginson. 2003. "Creditor Rights, Enforcement and Debt Ownership Structure: Evidence from the Global Syndicated Loan Market." Journal of Financial and Quantitative Analysis 38 (1):37-60. 
Garcia-Appendini, Emilia, Stefano Gatti, and Giacomo Nocera. 2017. "Covered Bonds, Asset Encumbrance and Bank Risk: Evidence from the European Banking Industry." AFFI International Conference 2017. http://www.fmaconferences.org/Boston/_CoveredBonds_FMA_Boston.pdf.

Gatti, Stefano, ed. 2012. Project Finance in Theory and Practice. Academic Press.

2013. Key Features of Long-Term Investments and Implications for Investors - Financial Stability Board Financial Regulation and the Provision of Long-Term Investment Finance. Basel (June).

Gatti, Stefano, Stefanie Kleimeier, William Megginson, and Alessandro Steffanoni. 2013. "Arranger Certification in Project Finance." Financial Management 42 (1): 1-40.

Hammami, Mona, Jean-Francois Ruhashyankiko, and Etienne B. Yehoue. 2006. "Determinants of Public-Private Partnerships in Infrastructure.” IMF Working Paper WP/o6/99.

Hansakul, Syetarn, and Hannah Levinger. 2016. "Asia Infrastructure Financing: Getting It Right would Lift Medium-Term Growth.” Deutsche Bank Research, Current Issues: Emerging Markets.

Hanson, Samuel, Andrei Shleifer, Jeremy C. Stein, and Robert W. Vishny. 2014. "Banks as Patient FixedIncome Investors.” NBER Working Paper No. 20288. http://www.nber.org/papers/w20288.pdf.

Hart, Oliver. 2003. "Incomplete Contracts and Public Ownership: Remarks, and an Application to Public-Private Partnerships.” The Economic Journal 113: C69-C76.

Holmström, Bengt, and Jean Tirole. 1998. "Private and Public Supply of Liquidity." Journal of Political Economy 106 (1): 1-40.

Inderst, Georg. 2010. “Infrastructure as an Asset Class.” EIB Papers 15 (1): 70-104.

Ivashina, Victoria, David S. Scharfstein, and Jeremy C. Stein. 2012. "Dollar Funding and the Lending Behavior of Global Banks.” NBER Working Paper No. 18528. http://www.nber.org/papers/w18528.pdf.

Kashyap, Anil., Raghuram Rajan, and Jeremy C. Stein. 2002. "Banks as Liquidity Providers: An Explanation for the Coexistence of Lending and Deposit-Taking." Journal of Finance 57 (1):33-73.

Kashyap, Anil, and Jeremy C. Stein. 1994. "Monetary Policy and Bank Lending." In Monetary Policy, edited by Gregory Mankiw, 221-61. University of Chicago Press.

Kirti, Divya. 2017. "Why Do Bank-Dependent Firms Bear Interest-Rate Risk?” IMF Working Paper WP/17/3.

Ma, Tianze. 2016. "Basel III and the Future of Project Finance Funding." Michigan Business \& Entrepreneurial Law Review 6 (1): 109-26.

Mirzaei, Ali, and Zeynab Mirzaei. 2011. "Bank-Specific and Macroeconomic Determinants of Profitability of Middle Eastern Banking." Iranian Economic Review 16 (2): 101-28.

Organisation for Economic Co-operation and Development (OECD). 2014. Private Financing and Government Support to Promote Long-term Investments in Infrastructure. Paris. 
Pham, Thi Hong Hanh. 2015. "Determinants of Bank Lending." Working Papers, HAL. https://hal.archives-ouvertes.fr/hal-01158241.

Sorge, Marco, and Blaise Gadanecz. 2004. "The Term Structure of Credit Spreads in Project Finance." BIS Working Papers No. 159. https://www.bis.org/publ/work159.pdf.

Subramanian, Krishnamurthy, and Frederick Tung. 2016. "Law and Project Finance." Journal of Financial Intermediation 25 (C): 154-77.

Vecchi, Veronica, Marco Airoldi, and Stefano Caselli. 2015. “Closing PPP’s Gaps in Italy: From Legal Microsurgery to Managerial Flow." In Managerial Flow, edited by Veronica Vecchi, Ben Farr-Wharton, Rodney Farr-Warthon, and Manuela Brusoni. Abington: Routledge.

Vecchi, Veronica, Mark Hellowell, Raffaele della Croce, and Stefano Gatti. 2017. "Government Policies to Enhance Access to Credit for Infrastructure-Based PPPs: An Approach to Classification and Appraisal." Public Money and Management 37 (2): 133-40.

Visconti, Roberto. 2012. "Inflation Risk Management in Project Finance Investments." International Journal of Finance and Accounting 1 (6): 198-207.

World Bank. 2017. Doing Business 2017: Equal Opportunity for All. Washington, DC.

World Bank, ADB, and Inter-American Development Bank. 2014. Public-Private Partnerships Reference Guide Version 2.0. Washington, DC.

World Economic Forum (WEF). 2013. Strategic Infrastructure: Steps to Prepare and Accelerate PublicPrivate Partnerships. Geneva. 


\section{An Empirical Analysis of the Factors that Influence Infrastructure Project Financing by Banks in Select Asian Economies}

The paper examines the factors influencing bank lending to infrastructure projects in key Asian countries. The focus is on projects developed through the public-private partnership (PPP) modality. The analysis indicates that banks largely base lending decisions on macroeconomic factors rather than on project finance considerations. The results accordingly suggest that the project finance modality has not yet been mainstreamed into the general financing considerations of Asian banks. Thus policy makers may focus more on reducing macroeconomic risk in order to expand the scope of bank lending to PPP infrastructure projects.

\section{About the Asian Development Bank}

ADB is committed to achieving a prosperous, inclusive, resilient, and sustainable Asia and the Pacific, while sustaining its efforts to eradicate extreme poverty. Established in 1966, it is owned by 67 members48 from the region. Its main instruments for helping its developing member countries are policy dialogue, loans, equity investments, guarantees, grants, and technical assistance. 